1

4

5 6

7

8

9

10

11

12

13

14

15

16

17

18

19

20

21

22

23

24

(

0

1
5 6

17

8

9

20

Timothy J. Hieger ${ }^{1 *}$, Rudolph Serbet ${ }^{1}$, Carla J. Harper ${ }^{1}$, Thomas N. Taylor ${ }^{1}$, Edith L. Taylor ${ }^{1}$, Erik L. Gulbranson ${ }^{2}$

Erik L. Gulbranson ${ }^{2}$

\title{
Cheirolepidiaceous diversity: an anatomically preserved pollen cone from the Lower Jurassic of southern Victoria Land, Antarctica
}

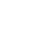

8

\footnotetext{
${ }^{1}$ Department of Ecology and Evolutionary Biology, and Natural History Museum and Biodiversity Institute, University of Kansas, Lawrence, KS 66045-7534, U.S.A.
}
${ }^{2}$ Department of Geosciences, University of Wisconsin-Milwaukee, Milwaukee, WI 53201-0413, U.S.A.

* Corresponding author. Tel.: ++1 785-864-4255; E-mail address: tihm@ku.edu 


\section{Introduction}

Jurassic floras are well known from the Antarctica Peninsula area. Members of the

27 Swedish South Polar Expedition (1901-1903) collected some of the first plant specimens from Hope Bay on Trinity Peninsula (Halle, 1913; Cantrill and Poole, 2012), which has been variously dated as Lower Jurassic to Lower Cretaceous (Gee, 1987; 1989; Rees and Cleal, 2004). Petrographic and geochronological analyses by Hunter et al. (2005) indicated that the Botany Bay Group is Middle Jurassic. The floras are diverse, e.g., liverworts (Schizolepidella spp.), sphenophytes (Equisetum spp.), ferns (e.g., Cladophlebis, Coniopteris, Dictyophyllum, Goeppertella, Hausmannia, Matonidium, Spesia, Sphenopteris, Todites), seed ferns (e.g., Archangelskya, Dicroidium, Komlopteris, Pachypteris), Caytoniales (Caytonanthus), cycadophyte foliage (e.g., Ctenis, Otozamites, Pseudoctenis, Taeniopteris, Weltrichia, Williamsonia, Zamites), conifers (e.g., Araucarites, Brachyphyllum, Elatocladus, Pagiophyllum)

37 (Gee, 1987, 1989; Rees and Cleal, 2004, and references therein; Ociepa, 2007; Ociepa and 38 Barbacka, 2011). In contrast to the Antarctic Peninsula, little is known about Jurassic plant life on the province that is related to the continental flood basalts of South Africa (Karoo) and South America (Chon Aike) (Riley and Knight, 2001), along the central Transantarctic Mountains.

44 Fossil plants of Jurassic age on the continent are found only in a few, exceptional sites where 45 sedimentary interbeds occur within the volcanics. Compression and permineralized plant fossils have been described from the Lower Jurassic Shafer Peak Formation in northern Victoria Land

47 (Bomfleur and Kerp, 2010; Bomfleur et al., 2007, 2011a, 2011b; Schöner, et al. 2007). In 
48 addition, several examples of silicified conifers have been described from the Jurassic of 49 Antarctica, including trees engulfed by lava flows from northern Victoria Land (Jefferson et al., 50 1983), silicified tree trunks from Brebbia and Ramírez Nunataks (Antarctic Peninsula; del Valle 51 et al., 1997), a single tree stump from the Coombs Hills in southern Victoria Land (Garland et 52 al., 2007), and permineralized woody axes from Suture Bench east of the Gair Mesa in northern 53 Victoria Land (Bomfleur et al., 2011b; Harper et al., 2012). Permineralized peat deposits from 54 Storm Peak in the central Transantarctic Mountains have yielded an anatomically preserved fern 55 petiole, Polyphacelus stormensis (Yao et al., 1991). Of these rare Jurassic sites, to date, the most 56 extensive and fossiliferous deposit is at Carapace Nunatak in southern Victoria Land (Townrow, 57 1967a; Ball et al., 1979; Babcock et al., 2006). In addition to silicified Jurassic wood, there is evidence for reproductive remains of 59 conifers from Antarctica (e.g., Plumstead, 1962, Townrow 1967a; 1967b). Dispersed staminate 60 cones belonging to Classostrobus Alvin, Spicer et Watson (Alvin et al., 1978) and containing in 61 situ Classopollis pollen, and other cheirolepidiaceous cones have been found on other continents 62 (see Van Konijnenburg-van Cittert 1987; Watson 1988; supplemental material); these are often 63 attached to or associated with other macrofossils belonging to the family. Most of what is known 64 about cheirolepidiaceous fossils is from compression-type preservation; discoveries and 65 descriptions of permineralizations are rare. Only a single permineralized cheirolepidiaceous 66 pollen cone has been described previously, Classostrobus crossii Rothwell et al. (2007), from

67 Middle Jurassic calcarerous nodules from southern England (Rothwell et al., 2007). Here we 68 describe a new species of anatomically preserved conifer pollen cone based on five specimens, 69 belonging to the Cheirolepidiaceae, that were discovered in Lower Jurassic sedimentary 70 interbeds on Carapace Nunatak, southern Victoria Land, Antarctica. The specimens described in 
71 this report are the first examples of permineralized cheirolepidiaceous pollen cones from the

72 Southern Hemisphere, and offer additional details about the anatomy and histology of the

73 staminate cones of this extinct family.

75 Geological setting, materials, and methods

76

\subsection{Geological setting}

The collection site is located within the Ferrar Large Igneous Province (FLIP), which is a linear $3500 \mathrm{~km}$ belt of tholeiitic rocks (Elliot and Fleming, 2004) that contains occasional permineralizations. The cones are preserved in lake sediments within laminated chert. The Lower Jurassic chert blocks containing the fossils used in this study were collected from a morainedebris field on the E-NE side of Carapace Nunatak, southern Victoria Land, central Transantarctic Mountains, Antarctica (76 53' S, 159 25' E, elevation 2149 m, Convoy Range Quadrangle) during the 1993-1994, 1997-1998, and 2011-2012 field seasons (Figure 1, A-C).

The rocks of the Kirkpatrick Basalt and Carapace Sandstone Member of the Mawson Formation at Carapace Nunatak are cross-cut by several faults (Bradshaw, 1987), but generally consist of subaerial basalt flows overlain by the volcaniclastic sandstone and breccia of the Carapace Sandstone. This is overlain by subaerial basaltic flows and columns of palagonite and basaltic pillows of the Kirkpatrick Basalt (Ballance and Watters, 1971). The fossil-bearing cherts occur as 2-6 m long pods or lenses set between palagonitic breccia and pillow basalts (Figure 1, D). The cherts display several physical features (Figure 1, E): millimeter-scale laminations, flame structures, diapirs, millimeter-scale normal faults that penetrate some laminae, rupturing of lamina sets, and intense folding of the lamina sets. A rough stratification of the chert and 
93 limestone lenses exists, but lateral continuity of the deposits does not occur due to the prevalence 94 of subaqueous basaltic lava flows in this stratigraphic interval.

The deformation features indicate the material was initially soft and underwent a loss in

96 volume prior to or concurrent with lithification. These lenses are interpreted as either rafts of

97 lacustrine sediment during a single prolonged emplacement of a lava delta, or as rafts of material

98 that was deposited in between two successive lava flows (Bradshaw, 1987). The fossil-bearing

99 cherts are interpreted as freshwater (lacustrine) deposits that have been affected by various

100 aspects of active volcanism (Ballance and Watters, 1971). Although our recognition of different

101 scales of soft-sediment deformation and volume-loss features within the chert layers is consistent

102 with Magadi-type chert (Eugster, 1967; Surdam et al., 1972; Krainer and Spötl, 1998), which

103 forms from the early diagenetic conversion of the Na-rich phyllosilicate mineral magadiite to

104 chert in alkaline lakes or from alkaline groundwaters (Rooney et al., 1969). Magadi-type chert is

105 unique among abiogenic cherts in that it preserves evidence of soft-sediment deformation and

106 desiccation due to its formation from soft beds of magadiite (Krainer and Spötl, 1998). At the

107 type locality, Lake Magadi in the Kenyan Rift Valley, magadiite is thought to form via a Na-rich

108 influx of hydrothermal fluid and a high silicon concentration (Jones et al., 1967). The presence of

109 Magadi-type chert in these lacustrine deposits would suggest that the Early Jurassic lake near

110 Carapace Nunatak was likely alkaline, possibly fed by hydrothermal fluids. The presence of

111 limestone lenses between palagonitic and basaltic pillows attests to lake water $\mathrm{pH}$ values near

112 neutral, and likely indicates temporal variation, at an unknown scale, in the geochemistry of

113 these lake waters. 


\subsection{Materials}

The fossiliferous chert blocks from Carapace Nunatak were initially described by Gunn and Warren (1962), and preliminary studies describing and discussing the fossil floras and faunas have been investigated by multiple authors (e.g., Plumstead, 1962, Townrow, 1967a;1967b, Babcock et al., 2006, Ribecai, 2007). Within the chert blocks used in this study, we have observed an abundance of fusainized plant material and animal remains. The fine-grained matrix has preserved several layers that contain abundant plant fossils, including various taxa of fern pinnules, rachides and rhizomes, at least three conifer taxa represented by vegetative and reproductive structures, isolated ovules, and cycadophyte foliage. Intermixed within this flora are various arthropods - an abundance of shallow-water dwelling conchostracans and other ephemeral freshwater crustaceans (Ballance and Watters, 1971; Ball et al., 1979; Shen, 1994).

\subsection{Methods}

Five permineralized pollen cones were analyzed in this study. The pollen cones are preserved in various planes of section and range from complete to fragmentary. Individual slabs containing two cones on the same surface are indicated as alpha and beta. Chert blocks were cut, polished, etched with $48 \%$ hydrofluoric acid, rinsed, and peeled using the standard acetate peel technique (Joy et al., 1956; Galtier and Phillips, 1999). A total of 177 serial peels were mounted on glass slides with Eukitt ${ }^{\circledR}$ mounting medium (O. Kindler, Freiburg, Germany). Pollen diameters were acquired using a Zeiss transmitted-light compound microscope. Scanning electron microscopy (SEM) images were acquired from peels mounted on SEM stubs with twosided tape and were sputter-coated with gold (15 nm) using a Q150T Turbo-pumped Sputter 
137 Coater (Quorum Technologies). Images were captured by a Versa 3D dual beam Scanning 138 Electron Microscope / Focused Ion Beam (FEI, Hillsboro, OR, USA). All SEM images were 139 obtained at an acceleration voltage of $20 \mathrm{kV}$, spot size 4.0, and were acquired with an Everhart 140 Thornley (ET) detector using built-in software (XT Microscope) of the FEI company. Digital 141 images of surface peels were taken on a Leica MZ16 manual fluorescence stereomicroscope with 142 an attached Leica DC500 digital camera. Images of slide-mounted peels were captured with a 143 Leica DC500 digital camera on a Leica DM5000B compound microscope. Additional 144 measurements were acquired using ImageJ 1.43u software (Abràmoff et al., 2004) and edited 145 (i.e., brightness, contrast, and color balance) using Adobe Photoshop CS4 version 11.0.2 (1990146 2010, (C) Adobe Systems). Pollen terminology is in concordance with Punt et al. (2007); note that 147 terms sexine 1, 2, 3 are in accordance with Punt et al. (2007) and differ from the same terms in 148 Taylor and Alvin (1984). Specimens include accession numbers: $17570 \mathrm{G}$ bot, 17607 A1 and B 149 top, 17613 F top alpha and beta, 17654 F3 bot, peels, SEM stub: J 2138, and slides: 29,698$15029,719,29,744-29,856$, and 29,910-29,951 and are housed in the Division of Paleobotany 151 Collections, Natural History Museum and Biodiversity Institute, University of Kansas (KUPB).

155 Division: Coniferophyta

156 Class: Coniferopsida

157 Order: Coniferales 
158 Family: Cheirolepidiaceae Takhtajan

159 Genus: Classostrobus Alvin, Spicer et Watson

160 Species: Classostrobus elliotii Hieger, Serbet, Harper, Taylor, Taylor et Gulbranson, sp. nov.

161 Specific Diagnosis: Cones ellipsoidal with bluntly pointed apex; microsporophylls stalked,

162 peltate (laminae rhomboidal distally), and helically arranged on the main axis. Sporophyll stalks

163 inflated at the base; comprised of a singular vascular strand and thick- and thin-walled

164 parenchymatous cells with interspersed transfusion tracheids. Distal from main cone axis,

165 sporophyll lamina with transfusion tracheids and some thick-walled parenchymatous cells.

166 Pollen sacs abaxial, vertically deflexed, arranged in an annular cluster with a central vascular

167 strand, attached to sporophyll stalk midway between cone axis and sporophyll lamina. Sporangia

168 bear in situ Classopollis pollen; cryptopore on distal surface, prominent subequatorial rimula

169 present, trilete on proximal surface, supratectal elements spinulose.

171 Etymology: The specific epithet is named in honor of Dr. David H. Elliot, for his numerous

172 contributions over the past 40 years that enhance our understanding of the geology and

173 stratigraphy of continental Antarctica, especially of Jurassic volcanic deposits.

174 Holotype (hic designatus): 17,654 F bot [Accession: slide nos. 29,910-29,951, SEM stub no. J

175 2138] (Plate I, 2, 4-7, Plate II, 1-12) this paper.

176 Paratypes: 17,613 F top alpha (Plate I, 3, 8, 9, 10) 17,613 F top beta (Plate I, 1) 
177 Repository: Natural History Museum and Biodiversity Institute, Division of Paleobotany

178 Collections (KUPB), University of Kansas, Lawrence, KS, USA

179 Type Locality: Carapace Nunatak, southern Victoria Land, Transantarctic Mountains, Antarctica $180 \quad\left(76^{\circ} 53^{\prime} \mathrm{S}, 159^{\circ} 25^{\prime} \mathrm{E}\right.$, elevation $2149 \mathrm{~m}$, Convoy Range Quadrangle)

181 Stratigraphic horizon: Carapace Sandstone Member, Mawson Formation, Ferrar Group

182 Age: Early Jurassic (Toarcian) (Elliot, 2013)

\subsection{Description}

The cones are ellipsoidal in longitudinal section, up to $5.5 \mathrm{~mm}$ in length with an average diameter of $2.8 \mathrm{~mm}(1.0-5.2 \mathrm{~mm}, \mathrm{n}=5)$, and the cone apex is bluntly pointed with helically arranged imbricate, peltate-shaped microsporophylls. The distal lamina is rhomboidal in face view with attenuate tips. The cone axis (Plate $\mathrm{I}, 1)$ is circular, approximately $0.5 \mathrm{~mm}$ in diameter and up to $4.4 \mathrm{~mm}$ long. Sporophylls (Plate I, 1,2) diverge from the main axis at approximately 90 degrees. Vascular tissue is poorly preserved in both longitudinal and transverse sections of the cone axis. Surrounding the vascular tissue are isodiametric parenchymatous cells $68 \mu \mathrm{m}(60-76$

$192 \mu \mathrm{m})$ in diameter with several cells containing opaque contents. Vascular tissue in the sporophyll

193 stalk (Plate I, 6) consists of a single bundle varying from 8 to 12 tracheids, each approximately 7 $194 \mu \mathrm{m}(5-10 \mu \mathrm{m})$ in diameter. The basal portion of stalk is about $0.7 \mathrm{~mm}$ in diameter narrowing to 195 approximately $0.5 \mathrm{~mm}$ and flaring distally (Plate I, 1, 2). At this point, the vascular strand 196 becomes diffuse and is gradually replaced by transfusion tracheids. Ultimately the transfusion 197 tissue (Plate I, 7) comprises about half of the sporophyll lamina and terminates approximately 
halfway through the distal lamina. Transfusion cells are ovoid, range up to $51 \mu \mathrm{m}$ in length and up to $24 \mu \mathrm{m}$ in diameter, and have scalariform wall thickenings (Plate I, 7). Resin ducts were not observed in any of the cones.

Microsporophylls consist of an expanded base, a circular stalk, and an expanded distal lamina. Distal laminae (Plate I, 4) are up to $2.7 \mathrm{~mm}$ long and $2.5 \mathrm{~mm}$ wide, and oriented perpendicular to the long axis of the stalk. The sporophyll epidermis (Plate I, 5) is divided into two parts on the outer distal lamina: an outer epidermis (Plate I, 5) made up of an uniseriate layer of thin-walled cells $17 \mu \mathrm{m}(10-33 \mu \mathrm{m})$ in diameter and an inner hypodermal layer (Plate I, 5) constructed of thicker-walled columnar cells $21 \mu \mathrm{m}(12-27 \mu \mathrm{m})$ long by $12 \mu \mathrm{m}(8-15 \mu \mathrm{m})$ wide. In some sections, an amorphous layer covers the epidermis and is interpreted as the remains of cuticle and/or epicuticular wax. Transfusion tracheids appear clustered near the distal end of the stalk along the vascular trace and extend into the distal lamina in a fan-like configuration among the parenchymatous cells of the sporophyll head. Isodiametric parenchymatous cells of the sporophylls are typically empty but are occasionally filled with opaque contents (Plate I, 4). These cells vary from 40 to $116 \mu \mathrm{m}$ in diameter.

Multiple sequences of serial peels indicate that a cluster of 4 to 7 ellipsoidal microsporangia in an annular arrangement (Plate I, 2, 3) is attached to the abaxial surface of the sporophyll stalk, equidistantly positioned between the distal lamina and the cone central axis (Figure 2). Microsporangia average $0.5 \mathrm{~mm}$ long and $0.3 \mathrm{~mm}$ in diameter. Vascular tissue is found in the center of the ring of sporangia (Plate I, 3 and 8). Some pollen sacs are devoid of pollen while others contain densely packed well-preserved or degraded grains. Sporangial wall cells are columnar and approximately $34 \mu \mathrm{m}(20-45 \mu \mathrm{m})$ long by $9 \mu \mathrm{m}(5-13 \mu \mathrm{m})$ wide. These cells are primarily filled with opaque contents (Plate I, 3) or may occasionally be empty (Plate I, 
221

222

223

224

225

226

227

228

229

230

231

232

233

234

235

236

237

9). Some sporangial walls are intact while others are ruptured possibly indicating pollen dispersal or damage to the sporangial wall. Bordering the microsporangial walls are numerous spheroidal tapetal orbicules (Plate II, 8, 12) that range from $0.8 \mu \mathrm{m}$ to $1.9 \mu \mathrm{m}$ in diameter.

Pollen sacs of Classostrobus elliotii are densely packed with pollen grains; identical pollen is (Plate II, 1) often found dispersed in other areas of the pollen cone, e.g., along the cone axis, outer sporangial walls, sporophyll stalks, and the abaxial surfaces of the sporophyll laminae. Some of the grains are in tetrads (Plate II, 2), but most occur as individual grains. In equatorial view, the pollen is globose and shows a size difference from the proximal to the distal (or vice-versa) poles; equatorial diameters of the individual grains are approximately $30 \mu \mathrm{m}(18-$ $60 \mu \mathrm{m} ; \mathrm{n}=123)$. Examination of these grains indicates features that are consistent with Classopollis pollen, including a distal cryptopore (Plate II, 3, 4, 5), subequatorial furrow or rimula (Plate II, 3, 6, 7), internal equatorial striae (Plate II, 6, 7, 9), and a proximal trilete (Plate II, 8,9$)$. The cryptopore is $3.5-4.4 \mu \mathrm{m}$ in diameter. The rimula extends around the pollen grain and is approximately $1.5 \mu \mathrm{m}(1.0-1.8 \mu \mathrm{m})$ wide. In proximal view, laesurae of the trilete (Plate II, 8) are 6.6-12.8 $\mu \mathrm{m}$ long. Anastomosing bands of striae (Plate II, 6) are rarely seen in external view; however, internal views from SEM images reveal linear arrangements of infratectal columellae indicative of striations.

Details of the pollen wall are well preserved and consist of an outer sexine and inner nexine layer, and the infrastructure of the grains is reticulate to pseudoreticulate. Layers 1-3 of the sexine (Plate II, 10) are approximately $1.9 \mu \mathrm{m}(1.7-2.1 \mu \mathrm{m})$ thick all together and are represented by infratectal columellae (sexine 1), an inner tectum (sexine 2), and supratectal spinules (sexine 3) in a discordant pattern. Supratectal spinules are conical, wide at the base and thinly tapered toward the tip. These wall structures average approximately $320 \mathrm{~nm}(240-530 \mathrm{~nm})$ 
244 long. The distal and proximal surfaces have numerous columellae (sexine 1) that protrude 245 inwards toward the nexine and are about $890 \mathrm{~nm}(740-1000 \mathrm{~nm})$ long by $450 \mathrm{~nm}(260-740 \mathrm{~nm})$

246 wide. The tectum (sexine 2) between the spinules and columns of the sexine is approximately

$247330 \mathrm{~nm}(210-440 \mathrm{~nm})$ thick. In some grains, the nexine (Plate II, 5, 11) is around $280 \mathrm{~nm}(210-$

$248330 \mathrm{~nm}$ ) thick. Broken grains allow for the internal examination of structures such as the

249 proximal trilete (Plate II, 9). This triangular structure has equidistant arms that are about $12 \mu \mathrm{m}$

250 long. Internal views of the grains reveal linear arrangements (Plate II, 7, 9) of the infratectal

251 columellae, and 3-5 equatorial striations that appear between the columellae below the rimula.

252 Up to five Brachyphyllum-type leaves are in close association with these cones (Plate I, 2,

253 10). There was no direct anatomical connection between the leaves and the pollen cones used in

254 this study. These leaves appear near the basal region of the cone and attenuate before extending

255 the entire length of the cones; the leaves are incomplete but include some morphological and

256 anatomical features. Leaves are $0.4-0.5 \mathrm{~mm}$ thick and $1.3-1.9 \mathrm{~mm}$ wide. Ground tissue is of

257 isodiametric cells, $66 \mu \mathrm{m}(30-123 \mu \mathrm{m})$ in diameter, which are primarily filled with opaque

258 contents. Each leaf contains a single vascular strand (Plate I, 10), consisting of about nine

259 metaxylem tracheids 5-6 $\mu \mathrm{m}$ in diameter together with a few protoxylem tracheids. There is a

260 space next to the xylem tissue that presumably represented the position of the phloem.

261 Surrounding the vascular tissue of several associated leaves are round cells (Plate I, 10) of

262 unknown affinities that may represent some type of secretory cell or a form of transfusion tissue.

263 Such cells contain contents which may also represent some type of thick-walled fungal hyphae.

264 These cells are between $10-25 \mu \mathrm{m}$ in diameter with walls that are $2-5 \mu \mathrm{m}$ thick. 


\section{Discussion}

The Cheirolepidiaceae is a large family of important extinct Mesozoic conifers (Alvin, 1982; Watson, 1988; Axsmith and Jacobs, 2005; Escapa et al., 2012; Stockey and Rothwell, 2013), which produce a diverse range of growth habits (Watson, 1988; Taylor et al., 2009). Spanning the Late Triassic to the Cretaceous, cheirolepidiaceous plants were components of coastal environments inundated by tides (Upchurch and Doyle, 1981) and one of the dominant components of forests on several continents (Vakhrameev, 1970; Alvin, 1982; Watson, 1988; Taylor et al., 2009; Stockey and Rothwell, 2013). Cheirolepidiaceous plants were widely distributed geographically with most examples at low paleolatitudes (Alvin et al., 1978; Alvin, 1982). To date, the majority of reports of cheirolepidiaceous macrofossils are from the Northern Hemisphere with fewer examples from the Southern Hemisphere (Alvin, 1982; Francis, 1983; Watson 1988; Taylor et al., 2009; Escapa et al., 2012). Classopollis pollen is distributed worldwide, but is rare at higher paleolatitudes (Vahkrameev, 1970; Brenner, 1976; Alvin, 1983). The pollen type of the Cheirolepidiaceae (Classopollis) is present on all Gondwana continents during the Early Jurassic (Grant-Mackie et al., 2000). Therefore, the discovery of the permineralized cheirolepidiaceous pollen cones provides evidence of their presence in Antarctica during the Jurassic.

\subsection{General comparisons}

Previous to this study, there was a single coniferous pollen cone, Masculostrobus warrenii Townrow, described from the Carapace Nunatak locality (Townrow, 1967b). This cone is $8 \mathrm{~mm}$ long and $5 \mathrm{~mm}$ wide with rhomboidal microsporophyll distal laminae, but it contains 
saccate pollen. Since one of the unifying characters of the Cheirolepidiaceae is Classopollis-type pollen (Alvin et al., 1978), M. warrenii clearly cannot be assigned to the Cheirolepidiaceae and was suggested by Townrow (1967b) to share affinities with the Podocarpaceae.

Classostrobus elliotii cones contain many unique characters that provide the basis for a new species, such as helically arranged microsporophylls, and a cluster of four to seven pollen sacs that are attached approximately midway on the abaxial microsporophyll stalk in an annular arrangement. The specimens used in this study are also similar in some characters to other cheirolepidiaceous pollen cones from different localities (see Van Konijnenburg-van Cittert, 1987), i.e., cones are small and simple, have helically arranged peltate microsporophylls with rhomboidal laminar heads situated around a central axis, and contain Classopollis pollen (Alvin, 1983; Rothwell et al., 2007). Cheirolepidiaceous cones have been found at other localities attached to or associated with vegetative remains (e.g., Barnard, 1968; Lorch, 1968; Barnard and Miller, 1976; Alvin et al., 1978, 1994; Watson, 1982; Francis, 1983; Van Konijnenburg-van Cittert, 1987; Watson, 1988; Thévenard, 1993; Gomez et al., 2002; Axsmith et al., 2004; Barbacka et al., 2007; Yang, 2008; Kim et al., 2012; see supplemental material). Isolated pollen cones that contain Classopollis pollen are placed within the genus Classostrobus (Alvin et al., 1978). Comparison is difficult with other cheirolepidiaceous cones due to the lack of stomatal information or compressional views of the cones, since most cones have been described from compression/impressions (Rothwell et al. 2007; Archangelsky and Del Fueyo, 2010).

There has been a single report of an anatomically preserved, permineralized cheirolepidiaceous cone, Classostrobus crossii, of southern England (Rothwell et al., 2007), which is from the Middle Jurassic. Classostrobus crossii is larger than C. elliotii, with a length of $20 \mathrm{~mm}$ and width of $18 \mathrm{~mm}$; microsporophyll laminae are up to $11 \mathrm{~mm}$ long (Rothwell et al., 
311 2007), whereas microsporophyll laminae of C. elliotii are up to $2.7 \mathrm{~mm}$ long and the cones have

312 a maximum diameter of $5.2 \mathrm{~mm}$ and length of $5.5 \mathrm{~mm}$. The number of pollen sacs in C. crossii is

313 described as several and the microsporangia are situated abaxially at the juncture of the stalk and

314 basal heel of the distal lamina. The pollen sacs of C. elliotii occur approximately midway

315 between the microsporophyll head and cone axis and are attached to and the abaxial surface of

316 the microsporophyll stalk.

Characters available for comparison with previously described cones lacking internal

318 anatomy are cone shape and size, shape of the sporophyll head, pollen sac arrangement and

319 position, and pollen features (Rothwell et al., 2007). The largest pollen cone, Classostrobus

320 cathayanus Zhou (Zhou, 1983), is $23 \mathrm{~mm}$ in diameter and more than $20 \mathrm{~mm}$ long. Cones of

321 Tomaxiella biforme Archangelsky (Archangelsky and Gamerro, 1967) are the smallest, 2-3 mm

322 long and $1 \mathrm{~mm}$ wide. Classostrobus elliotii is up to $5.5 \mathrm{~mm}$ long and $5.2 \mathrm{~mm}$ wide with an

323 average diameter of $2.8 \mathrm{~mm}$. The overall shape of the microsporophylls is peltate, and the

324 microsporophyll heads are rhomboidal in face view like most other cheirolepidiaceous cones.

325 For further comparisons of all cheirolepidiaceous cones, see supplemental material.

\subsection{Microsporangia}

The pollen sacs of the Cheirolepidiaceae are typically situated on the abaxial surface of

329 the microsporophyll attached near the microsporophyll head. For the type species, Classostrobus rishra (Barnard) Alvin, Spicer et Watson (Alvin et al., 1978), six to eight pollen sacs are layered

331 on the abaxial surface of the microsporophyll stalk. The microsporangia of C. arkansensis

332 Axsmith, Krings et Waselkov (Axsmith et al., 2004) are located on the abaxial side of the 
333 sporophyll stalk near the basal inner region of the microsporophyll head. Abaxial positioning of 334 pollen sacs is also present in cones associated with the foliage taxa Hirmeriella airelensis Muir 335 et Van Konijnenburg-van Cittert (Muir and Van Konijnenburg-van Cittert, 1970), and

336 Frenelopsis (Schenk) sp. (Barale et al., 1988).

The number of pollen sacs per microsporophyll is variable within Classostrobus elliotii

338 cones, i.e., four to seven vertically deflexed pollen sacs, which occur in an annular cluster

339 attached to the abaxial sporophyll stalk. When compared to other cheirolepidiaceous cones, the

340 annular arrangement of the pollen sacs is a unique character of $C$. elliotii. Where observed, most

341 other staminate cones of the Cheirolepidiaceae have two to three pollen sacs per microsporophyll

342 or the number is unknown (Van Konijnenburg-van Cittert, 1987). Up to four pollen sacs are

343 observed in C. dalatzensis Yang (Yang, 2008), and cones belonging to Hirmeriella muensteri

344 (Schenk) Jung (Jung, 1968) have up to twelve microsporangia per microsporophyll. However,

345 Van Konijnenburg-van Cittert (1987) observed six microsporangia per microsporophyll in $H$.

346 muensteri.

In general, Jurassic cheirolepidiaceous pollen cones contain more pollen sacs per

348 microsporophyll relative to Cretaceous pollen cones (see supplemental material and references

349 therein). To date, evolutionary inferences and trends on the number and positioning of

350 microsporangia in the Cheirolepidiaceae are based on limited reports. Increased datasets on

351 pollen cones from permineralized material such as specimens from Carapace Nunatak may shed

352 additional light on this aspect of pollen cone evolution within this conifer family. 

numerous in deposits worldwide (Taylor et al., 2009; Zavialova et al., 2010a; 2010b). Previous studies of palynofloras from Carapace Nunatak have been interpreted as late Middle Jurassic

358 (Shang, 1997; Ribecai, 2007), which conflicts with Early Jurassic radiometric age constraints on 359 the timing of lava emplacement (Elliot, 2013). A more recent revision of the palynoflora of 360 Carapace Nunatak indicates that it is dominated by Classopollis pollen, which suggests that 361 members of the Cheirolepidiaceae were present (Bomfleur et al., 2014). Classopollis is said to be 362 the one reliable characteristic that allows assignment to the Cheirolepidiaceae, including pollen 363 cones (Watson, 1988), and the presence of in situ pollen of this type is a consistent characteristic 364 of Classostrobus cones (Alvin et al., 1978). Classostrobus elliotii contains numerous in situ

365 pollen grains that would be assigned to Classopollis, as they exhibit a distal cryptopore, 366 subequatorial furrow (rimula), equatorial striae, and a proximal trilete (Plate II). Striations are 367 rarely seen in light transmitted light microscopy, but are revealed as patterns in infratectal 368 columellae under SEM.

The average pollen diameter $(30 \mu \mathrm{m})$ of the Antarctic grains is comparable to that of 370 most other cheirolepidiaceous cones that contain Classopollis along with those from dispersed 371 pollen assemblages. Pollen grains associated with Classostrobus dalatzensis are reported to be as 372 small as $13 \mu \mathrm{m}$ (Axsmith et al., 2004). The largest pollen grains associated with 373 cheirolepidiaceous cones reported to date is $65 \mu \mathrm{m}$ from cones associated with Frenelopsis alata 374 (Hlustik and Konzalova, 1976). Equatorial diameters of the solitary, mature pollen within 375 Classostrobus elliotii are as small as $18 \mu \mathrm{m}$ and can be as large as $60 \mu \mathrm{m}$. Smaller, dispersed 376 pollen grains associated with $C$. elliotii may be interpreted as aborted, but larger grains may be 377 interpreted as possible forms of polyploid pollen (see Kürschner et al., 2013). The infrastructure 
378 of $C$. elliotii in situ pollen grains is reticulate to pseudoreticulate making the striae appear to be

379 absent or vague, which is similar to other cheirolepidaceous pollen grains from the Early

380 Jurassic. The pollen striae of C. elliotii are similar to the sporae dispersae species C. chateaunovi

381 and C. kieseri Reyre (Reyre, 1970) that lack or have vague striations. The combination of no

382 striations to vague striations and possession of reticulate infratectal patterns among species with

383 similar supratectal elements is common among Early Jurassic Classopollis species (Reyre,

384 1970). Similar to these Early Jurassic species of Classopollis, the striae of C. elliotii pollen

385 grains are difficult to discern under light microscopy and are revealed as sinuous linear

386 arrangements of infratectal columellae under SEM. When compared to the Middle Jurassic

387 Classopollis pollen of southern England, supratectal elements of Classostrobus crossii grains

388 described as spines (Rothwell et al., 2007) are similar in shape to the surface ornaments of $C$.

389 elliotii pollen, but the infratectal columellae of C. crossii is differentiated so that anastomosing

390 striae are distinct. In situ mature pollen grains of $C$. comptonensis from the Lower Cretaceous

391 Wealden beds provided the opportunity of ultrastructural studies by Taylor and Alvin (1984),

392 and revealed that the grains exhibit distinct striae with supratectal spinules. Pollen of

393 Classostrobus arkansensis Axsmith et al. (2004) of the United States shares these characteristics

394 with C. comptonensis in situ grains (Axsmith et al., 2004). The pollen of C. comptonensis is

395 similar to the pollen of the Early Cretaceous pollen cones of Spain, C. turolensis and $C$.

396 ugnaensis Gomez et al. (2002), in possessing distinct striae and microechinate supratectal

397 ornaments, which were described based on in situ and dispersed pollen from the same locality

398 (Gomez et al., 2002).

399 Infrastructure, supratectal ornamentation, and striations have recently been used in 400 Argentina to assign taxonomic value to Classopollis sporae dispersae discussed by Reyre (1970) 
401 and to introduce new species (Villar de Seoane, 2014), and the differentiation of infrastructure 402 among species of Classopollis has been discussed by Zavialova et al. (2010a, 2010b). One 403 concern about taxonomic placement into dispersed species based on these pollen characters is 404 that they may represent different stages in pollen development, but the pollen characters of 405 Classostrobus comptonensis discussed by Taylor and Alvin (1984) were based on samples from 406 interpreted mature and immature cones, which helped to clarify differences between 407 developmental morphologies of the pollen wall. Therefore, the pollen cones of C. elliotii (Early

408 Jurassic), C. crossii (Middle Jurassic), C. comptonensis (Early Cretaceous) may all be interpreted 409 as mature (i.e., complete tetrad development) with developed pollen walls, thus providing insight 410 into ultrastructural differences of in situ pollen. Through comparisons with ultrastructure of 411 pollen from other cheirolepidiaceous cones, the pollen characters of $C$. elliotii assist in 412 supporting the hypothesis of Reyre (1970) that in the early evolution of the Cheirolepidiaceae 413 (Late Triassic-Early Jurassic), the pollen cones produced pollen having a less differentiated 414 arrangement of infratectal columellae than in more evolved (i.e., later) forms (Middle Jurassic415 Cretaceous) yet similar supratectal elements, in this case, echinate features. If factors other than 416 grain maturity, i.e., taphonomy, preservation, and preparation, have little effect on these aspects 417 of Classopollis ultrastrucure, this adds further support for the numerous different species of 418 identified Classopollis pollen by advancement of morphological traits and strengthens the 419 morphological diversity known for this extinct conifer family. 
423 Cheirolepidiaceae to the southernmost Lower Jurassic paleolatitude to date. During the Lower

424 Jurassic, Carapace Nunatak was located at $\sim 60^{\circ} \mathrm{S}$ paleolatitude. Other occurrences have been

425 noted as far south as Patagonia, Argentina (e.g., Archangelsky, 1968; Archangelsky and

426 Gamerro, 1967; Escapa et al., 2012, 2013) and Australia (e.g., Pole, 2000; Tosolini et al., 2015).

427 This is also the first report of macrofossil evidence of the Cheirolepidiaceae from Antarctica;

428 therefore, the specimens used in this study extend the biogeographical distribution of this family

429 to all present-day continents.

A number of cheirolepidiacean plants are considered to have been halophytes and were

431 clearly thermophilous (Alvin, 1982), although the family was also successful in temperate

432 climates (Watson, 1988). Crustaceans, insects, and plants collected from Carapace Nunatak

433 suggest a non-arid, temperate or possibly warmer climate, based on comparisons to extant

434 representatives (Ball et al., 1979). Deposits represent freshwater, ephemeral pond, and deep-lake

435 environments (Stigall et al., 2008). Plants have been used as proxies for paleoclimate and as

436 paleoenvironmental indicators (Rees et al., 2000; Taylor and Ryberg 2007). The

437 Cheirolepidiaceae can also be used as a proxy for the Carapace Nunatak locality during the Early

438 Jurassic, which suggests that it may have been a xeric or halophytic habitat based on specific

439 characters of this Mesozoic conifer family. The Cheirolepidiaceae typically show xeromorphic

440 characters, such as thick, succulent shoots, and reduced scale-like leaves, and this may explain

441 how this plant was able to grow in a warm environment close to active volcanism. Although

442 more paleobotanical data, e.g., cuticle and stomatal information, are needed to further understand

443 the paleoenvironment of the locality, this discovery adds to the wide range of habitats occupied

444 by this important Mesozoic conifer family. 


\section{Conclusions}

The presence of a cheirolepidiaceous pollen cone in Lower Jurassic rocks from Carapace

448 Nunatak, Antarctica bridges the gap between southern and northern Gondwanan continents and 449 provides evolutionary insight into this biogeographically important extinct conifer group. This

450 discovery extends the biogeographical range of macrofossils of the Cheirolepidiaceae during the 451 Early Jurassic to its southernmost point and is the highest paleolatitude, i.e., $\sim 60^{\circ} \mathrm{S}$ paleolatitude, 452 occurrence. Classostrobus elliotii is the first anatomically preserved cheirolepidiaceous cone 453 discovered in the Southern Hemisphere. The cones are small and simple, similar to other cones 454 of the Cheirolepidiaceae. In situ pollen of Early Jurassic cheirolepidiacean pollen cones like that 455 of C. elliotii provides additional data for preexisting hypotheses of Classopollis ultrastructural 456 evolution. The number and position of pollen sacs is considered taxonomically important for 457 understanding the evolution of pollen cones in conifers, and this study provides new information 458 on key taxonomic characters for a group of conifers, which is phylogenetically poorly resolved, 459 in order to better understand the evolution on the morphology of pollen cones belonging to the 460 Cheirolepidiaceae.

Plumstead (1962) described a small shoot belonging to Brachyphyllum cf. expansum

462 Sternberg from the Carapace Nunatak locality (Townrow 1967a). The associated leaves of 463 Classostrobus elliotii resemble those of Brachyphyllum and appear to be thick, fleshy, and 464 triangulate. Whether C. elliotii may have been produced by a shoot that bears this type of leaf 465 merits further investigation. Additionally, isolated ovules have been observed in cherts from the 466 Carapace Nunatak locality, which increases the likelihood of finding ovulate cones or the seed- 
467 bearing reproductive organs of these plants. We are hopeful that additional studies in progress

468 will likely provide the opportunity of developing a whole-plant concept for this extinct conifer.

\section{Acknowledgments}

Financial support was provided by the National Science Foundation (Grant ANT-

4721142495 to E.L.T. and T.N.T.). T.J.H. extends appreciation for summer funding through the KU

473 Undergraduate Biology Program Research Award. We thank Dr. Prem Thappa and Ms. Heather

474 Shinogle of the KU Bioimaging Facility for assistance in acquiring SEM images, Dr. A.-L.

475 Decombeix (Montpellier, France) for assistance with translations, Dr. Gar W. Rothwell (Athens, 476 OH, USA), Dr. Ruth A. Stockey (Corvallis, OR, USA) and Dr. B. Bomfleur (Stockholm, 477 Sweden) for discussions and constructive comments on this paper, Sara L. Taliaferro for the 478 illustration, and two anonymous reviewers for their helpful comments on an earlier draft of this 479 manuscript.

\section{References}

482 Abràmoff, M.D., Magalhães, P.J., Ram, S.J., 2004. Image processing with ImageJ. Biophotonics International 11, 36-42.

484 Alvin, K.L., 1982. Cheirolepidiaceae: biology, structure and paleoecology. Review of Palaeobotany and Palynology 37, 71-98.

486 Alvin K.L., 1983. Reconstruction of a Lower Cretaceous conifer. Botanical Journal of the Linnean Society 86, 169-176. 
Alvin, K.L., Spicer, R.A., Watson, J., 1978. A Classopollis-containing male cone associated with Pseudofrenelopsis. Palaeontology 21, 847-856.

Archangelsky, S., 1968. On the genus Tomaxellia (Coniferae) from the Lower Cretaceous of Patagonia (Argentina) and its male and female cones. Botanical Journal of the Linnean Society of London 61, 153-165.

Archangelsky, S., Gamerro, J.C., 1967. Pollen grains found in coniferous cones from the Lower Cretaceous of Patagonia (Argentina). Review of Palaeobotany and Palynology 5, 179_ 182.

Archangelsky S., Del Fueyo G.M., 2010. Endemism of Early Cretaceous conifers in western Gondwana. In: Gee C.T., (ed.), Plants in Mesozoic Time: Morphological Innovation, Phylogeny, Ecosystems, Indiana University Press, Bloomington, IN, pp. 247-270.

Axsmith, B.J., Krings, M., Waselkov, K., 2004. Conifer pollen cones from the Cretaceous of Arkansas: implications for diversity and reproduction in the Cheirolepidiaceae. Journal of Paleontology 78, 402-409.

Axsmith, B.J., Jacobs, B.F., 2005. The conifer Frenelopsis ramosissima (Cheirolepidiaceae) in the Lower Cretaceous of Texas: systematic, biogeographical, and paleoecological implications. International Journal of Plant Sciences 166, 327-337.

Babcock, L.E., Leslie, S.A., Elliot, D.H., Stigall, A.L., Ford, L.A., Briggs, D.E.G., 2006. The "preservation paradox": microbes as a key to exceptional fossil preservation in the Kirkpatrick Basalt (Jurassic), Antarctica. The Sedimentary Record 4, 4-8.

Ball, H.W., Borns Jr, H.W., Hall, B.A., Brooks, H.K., Carpenter, F.M., Delevoryas, T., 1979. Biota, age, and significance of lake deposits, Carapace Nunatak, Victoria Land, Antarctica. In: Laskar, B., Rao, C.S.R. (Eds.), Fourth International Gondwana 
Symposium: Papers, vol. 1. Hindustan Publishing Corporation, New Delhi, India, pp. 166-175.

513 514

515

516

517

518

519

520

521

522

523

524

525

526

527

528

529

530

531

532

533

Ballance, P.F., Watters, W.A., 1971. The Mawson Diamictite and the Carapace Sandstone, formations of the Ferrar Group at Allan Hills and Carapace Nunatak, Victoria Land, Antarctica. New Zealand Journal of Geology and Geophysics 14, 512-527.

Barale, G., Fernandez Marron, T., Alvarez Ramis, C., 1988. Étude de cônes mâles de Frenelopsis Schenk emend. Reymanówna et Watson, 1976 (Cheirolepidiaceae) du Crétacé supérieur de Torrelaguna (Province de Madrid-Espagne). Géobios 21, 187-199.

Bomfleur, B., Kerp, H., 2010. The first record of the dipterid fern leaf Clathropteris Brongniart from Antarctica and its relation to Polyphacelus stormensis Yao, Taylor et Taylor nov. emend. Review of Palaeobotany and Palynology 160, 143-153.

Bomfleur, B., Schneider, J., Schöner, R., Viereck-Götte, L., Kerp, H., 2007. Exceptionally wellpreserved Triassic and Early Jurassic floras from North Victoria Land, Antarctica. USGS Open-File Reports 2007-1047 (ea034): 4 pp. [Antarctica: A Keystone in a Changing World-Online Proceedings of the $10^{\text {th }}$ ISAES].

Bomfleur, B., Pott, C., Kerp, H., 2011a. Plant assemblages from the Shafer Peak Formation (Lower Jurassic), north Victoria Land, Transantarctic Mountains. Antarctic Science 23, $188-208$.

Bomfleur, B., Schneider, J.W., Schöner, R., Viereck-Götte, L., Kerp, H., 2011b. Fossil sites in the Continental Victoria and Ferrar groups (Triassic-Jurassic) of North Victoria Land, Antarctica. Polarforschung 80, 88-99.

Bomfleur, B., Schöner, R., Schneider, J.W., Viereck, L., Kerp, H., McKellar, J.L, 2014. From the Transantarctic Basin to the Ferrar Large Igneous Province-New palynostratigraphic age 
constraints for Triassic-Jurassic sedimentation and magmatism in East Antarctica. Review of Palaeobotany and Palynology 207, 18-37.

Bradshaw, M.A., 1987. Additional field interpretation of the Jurassic sequence at Carapace Nunatak and Coombs Hills, south Victoria Land, Antarctica. New Zealand Journal of Geology and Geophysics 30, 37-49.

Brenner, G.J., 1976. Middle Cretaceous floral provinces and early migrations of angiosperms. In: C.B. Beck (ed.), Origin and Early Evolution of Angiosperms, Columbia University Press, NY. pp. 23-47.

Cantrill, D.J., 2000. A new macroflora from the South Orkney Islands, Antarctica: evidence of an Early to Middle Jurassic age for the Powell Island Conglomerate. Antarctic Science $12,185-195$.

Cantrill D.J., Poole I., 2012. The Vegetation of Antarctica Through Geological Time. Cambridge University Press, New York, NY, 487 pp.

del Valle, R.A., Lirio, J.M., Lusky, J.C., Morelli, J.R., Nuñez, H.J., 1997. Jurassic trees at Jason Peninsula, Antarctica. Antarctic Science 9, 443-444.

Elliot, D.H., 2013. The geological and tectonic evolution of the Transantarctic Mountains: a review. In: Hambrey, M.J., Barker, P.F., Barrett, P.J., Bowman, V., Davies, B., Smellie, J.L., Tranter, M. (eds.), Antarctic Palaeoenvironments and Earth-Surface Processes. Geological Society, London, Special Publications 381, 7-35.

Elliot, D.H., Fleming, T.H., 2004. Occurrence and dispersal of magmas in the Jurassic Ferrar Large Igneous Province, Antarctica. Gondwana Research 7, 223-237. 
Escapa, I.H., Rothwell, G.W., Stockey, R.A., Cúneo, N.R., 2012. Seed cone anatomy of Cheirolepidiaceae (Coniferales): reinterpreting Pararaucaria patagonica Wieland. American Journal of Botany 99, 1058-1068.

Escapa, I.H., Cúneo, N.R., Rothwell, G., Stockey, R.A., 2013. Pararaucaria delfueyoi sp. nov. from the Late Jurassic Cañadón Calcáreo Formation, Chubut, Argentina: insights into the evolution of the Cheirolepidiaceae. International Journal of Plant Sciences 174, 458-470.

Eugster, H.P., 1967. Hydrous sodium silicates from Lake Magadi, Kenya: precursors of bedded chert. Science 157, 1177-1180.

Francis, J.E., 1983. The dominant conifer of the Jurassic Purbeck formation, England. Palaeontology 26, 277-294.

Galtier, J., Phillips, T.L., 1999. The acetate peel technique. In: Jones, T.P., Rowe, N.P. (eds.), Fossil Plants and Spores: Modern Techniques. The Geological Society, London, pp. 6770.

Garland, M.J., Bannister, J.M., Lee, D.E., White, J.D.L., 2007. A coniferous tree stump of late Early Jurassic age from the Ferrar Basalt, Coombs Hills, southern Victoria Land, Antarctica. New Zealand Journal of Geology and Geophysics 50, 263-269.

Gee, C.T., 1987. Revision of the Early Cretaceous flora from Hope Bay, Antarctica. University of Texas, Austin, Texas, USA. Ph.D. Dissertation. 165 pp.

Gee, C.T., 1989. Revision of the Late Jurassic/Early Cretaceous flora from Hope Bay, Antarctica. Palaeontographica. Abteilung B, Paläophytologie 213, 149-214.

Grant-Mackie, J.A., Aita, Y., Balme, B.E., Campbell, H.J., Challinor, A.B., MacFarlan, D.A.B., Molnar, R.E., Stevens, G.R., Thulborn, R.A., 2000. Jurassic palaeobiogeography of Australasia. In: Wright, A.J., Talent, J.A., Young, G.C., Laurie, J.R., (eds.), 
Palaeobiogeography of Australasian Faunas and Floras, Memoir of the Association of Australasian Palaeontologists 23, 311-354.

Gunn, B.M., Warren, G., 1962. Geology of Victoria Land between the Mawson and Mulock Glaciers, Antarctica. New Zealand Geological Survey Bulletin 71, 1-157.

Halle, T.G., 1913. The Mesozoic flora of Graham Land. Wissenschaftliche Ergebnisse der Schwedischen Südpolar-Expedition 1901-1903 3, 3-124.

Harper, C.J., Bomfleur, B., Decombeix, A.-L., Taylor, E.L., Taylor, T.N., Krings, M., 2012. Tylosis formation and fungal interactions in an Early Jurassic conifer from northern Victoria Land, Antarctica. Review of Palaeobotany and Palynology 175, 25-31.

Hluštík, A., Konzalová, M., 1976. Polliniferous cones of Frenelopsis alata (K. Feistm.) Knobloch from the Cenomanian of Czechoslovakia. Věstník Ústředního ústavu Geologického 51, 37-46.

Hunter M.A., Cantrill D.J., Flowerdew M.J., Millar I.L., 2005. Mid-Jurassic age for the Botany Bay Group: Implications for Weddell Sea Basin creation and southern hemisphere biostratigraphy. Journal of the Geological Society of London 162, 745-748.

Jefferson, T.H., Siders, M.A., Haban, M.A., 1983. Jurassic trees engulfed by lavas of the Kirkpatrick Basalt Group, northern Victoria Land. Antarctic Journal of the United States $18(5), 14-16$.

Jones, B.F., Rettig, S.L., Eugster, H.P., 1967. Silicate in alkaline brines. Science, 158, 13101314.

Joy, K.W., Willis, A.J., Lacey, W.S., 1956. A rapid cellulose peel technique in palaeobotany. Annals of Botany 20, 635-637. 
600

601

602

603

604

605

606

607

608

609

610

611

612

613

614

615

616

617

618

619

620

Jung, W., 1968. Hirmerella münsteri (Schenk) Jung nov. comb., eine bedeutsame Konifere des Mesozoïkums. Palaeontographica Abteilung B Paläophytologie 122, 55-93.

Krainer, K., Spötl, C., 1998. Abiogenic silica layers within a fluvio-lacustrine succession, Bolzano Volcanic Complex, northern Italy: a Permian analogue for Magadi-type cherts? Sedimentology 45, 489-505.

Kürschner, W.M., Batenburg, S.J., Mander, L., 2013. Aberrant Classopollis pollen reveals evidence for unreduced (2n) pollen in the conifer family Cheirolepidiaceae during the Triassic-Jurassic transition. Proceedings of the Royal Society B 280, 20131708. http://dx.doi.org/10.1098/rspb.2013.1708

Muir, M., Van Konijnenburg-van Cittert, J., 1970. A Rhaeto-Liassic flora from Ariel, northern France. Palaeontology 13, 433-442.

Ociepa, A.M., 2007. Jurassic liverworts from Mount Flora, Hope Bay, Antarctic Peninsula. Polish Polar Research 28, 31-36.

Ociepa, A.M., Barbacka, M., 2011. Spesia antarctica gen. et sp. nov.-a new fertile fern spike from the Jurassic of Antarctica, Polish Polar Research 32, 59-66.

Plumstead, E.P., 1962. Fossil floras from Antarctica. Trans-Antarctic Expedition 1955-1958, Scientific Reports 9, 1-132.

Pole, M.S., 2000. Mid-Cretaceous conifers from the Eromanga Basin, Australia. Australian Systematic Botany 13, 153-197.

Punt, W., Hoen, P.P., Blackmore, S., Nilsson, S., Le Thomas, A., 2007. Glossary of pollen and spore terminology. Review of Palaeobotany and Palynology 143, 1-81. 
621 Rees, P.M., Ziegler, A.M., Valdes, P.J., 2000. Jurassic phytogeography and climates: new data 622 and model comparisons. In: Huber, B.T., MacLeod, K.G., Wing, S.L., (eds.), Warm Climates in Earth History, Cambridge University Press, Cambridge, U.K., pp. 297-318.

624 625 626 627 628 629 630 631 632 633 634 635 636 637 638 639 640 641 642

Rees, P.M., Cleal, C.J., 2004. Lower Jurassic floras from Hope Bay and Botany Bay, Antarctica. Special Papers in Palaeontology 72, 1-90.

Reyre, Y., 1970. Stereoscan observations on the pollen genus Classopollis Pflug 1953. Palaeontology 13, 303-322.

Ribecai, C., 2007. Early Jurassic miospores from Ferrar Group of Carapace Nunatak, South Victoria Land, Antarctica. Review of Palaeobotany and Palynology 144, 3-12.

Riley, T.R., Knight, K.B., 2001. Age of pre-break-up Gondwana magmatism. Antarctic Science $13,99-110$.

Rooney, T.P., Jones, B.F., Neal, J.T., 1969. Magadiite from Alkali Lake, Oregon. American Mineralogist 54, 1034-1043.

Rothwell, G.W., Mapes, G., Hilton, J., Hollingworth, N.T., 2007. Pollen cone anatomy of Classostrobus crossii sp. nov. (Cheirolepidiaceae). International Journal of Coal Geology $69,55-67$.

Schöner, R., Viereck-Göette, L., Schneider, J., Bomfleur, B., 2007. Triassic-Jurassic sediments and multiple volcanic events in North Victoria Land, Antarctica: A revised stratigraphic model. USGS Open-File Reports 2007-1047 (SRP102): 5 pp. [Antarctica: A Keystone in a Changing World-Online Proceedings of the $10^{\text {th }}$ ISAES].

Shang, Y.-K. 1997. Middle Jurassic palynology of Carapace Nunatak, Victoria Land, Antarctica. Acta Palaeontologica Sinica 36, 170-186. 
643 Shen, Y., 1994. Jurassic conchostracans from Carapace Nunatak, southern Victoria Land,

644

645

646

647

648

649

650

651

652

653

654

655

656

657

658

659

660

661

662

663

664 Antarctica. Antarctic Science 6, 105-113.

Surdam, R.C., Eugster, H.P., Mariner, R.H., 1972. Magadi-type chert in Jurassic and Eocene to Pleistocene rocks, Wyoming. GSA Bulletin 83, 2261-2266.

Stigall, A.L., Babcock, L.E., Briggs, D.E.G., Leslie, S.A. 2008. Taphonomy of lacustrine interbeds in the Kirkpatrick Basalt (Jurassic), Antarctica. PALAIOS 23, 344-355.

Stockey, R.A., Rothwell, G.W. 2013. Pararaucaria carrii sp. nov., anatomically preserved evidence for the conifer family Cheirolepidiaceae in the Northern Hemisphere. International Journal of Plant Sciences 174, 445-457.

Taylor, T.N., Alvin, K.L., 1984. Ultrastructure and development of Mesozoic pollen: Classopollis. American Journal of Botany 71, 575-587.

Taylor, E.L., Ryberg, P.E., 2007. Tree growth at polar latitudes based on fossil tree ring analysis. Palaeogeography, Palaeoclimatology, Palaeoecology 255, 246-264.

Taylor, T.N., Taylor, E.L., Krings, M., 2009. Paleobotany: The Biology and Evolution of Fossil Plants, Second Edition. Academic Press, Amsterdam, The Netherlands, 1230 pp.

Tosolini, A.-M.P., McLoughlin, S., Wagstaff, B.E., Cantrill, D.J., Gallagher, S.J., 2015. Cheirolepidiacean foliage and pollen from Cretaceous high-latitudes of southeastern Australia. Gondwana Research 27, 960-977.

Townrow, J.A., 1967a. Fossil plants from Allan and Carapace Nunataks, and from the upper Mill and Shackleton glaciers, Antarctica. New Zealand Journal of Geology and Geophysics $10,456-473$.

Townrow, J.A., 1967b. On a conifer from the Jurassic of East Antarctica. Papers and 
Proceedings of the Royal Society of Tasmania 101, 137-149.

666

667

668

669

670

671

672

673

674

675

676

677

678

679

680

681

682

683

684

685

686
Upchurch, G.R., Doyle, J.A., 1981. Paleoecology of the conifers Frenelopsis and Pseudofrenelopsis (Cheirolepidiaceae) from the Cretaceous Potomac Group of Maryland and Virginia. In R.C. Romans (ed.), Geobotany. Plenum, New York, pp. 165-172.

Vakhrameev, V., 1970. Range and paleoecology of Mesozoic conifers: the Cheirolepidiaceae. Paleontological Journal 4, 12-25.

Van Konijnenburg-van Cittert, J.H.A., 1987. New data on Pagiophyllum maculosum Kendall and its male cone from the Jurassic of north Yorkshire. Review of Palaeobotany and Palynology 51, 95-105.

Venkatachala, B., Góczán, F., 1964. The spore-pollen flora of the Hungarian 'Kössen Facies'. Acta Geologica Hungarica 8, 203-228.

Villar de Seoane, L., 2014. Estudio morfológico del género Classopollis (Pflug) Pocock \& Jansonius (Cretácico, Argentina). Revista Brasileira de Paleontologia 17, 91-104.

Watson, J., 1988. The Cheirolepidiaceae. In: Beck, C.B. (ed.), Origin and Evolution of Gymnosperms, Columbia University Press, NY, pp. 382-447.

Yang, X.-J., 2008. A male cone of Pseudofrenelopsis dalatzensis with in situ pollen grains from the Lower Cretaceous of northeast China. Géobios 41, 689-698.

Yao, X., Taylor, T.N., Taylor, E.L., 1991. Silicified dipterid ferns from the Jurassic of Antarctica. Review of Palaeobotany and Palynology 67, 353-362.

Zavialova, N.E., Tekleva, M.V., Smirnova, S.B., Mroueh, M., 2010a. Exine ultrastructure in pollen grains of Classopollis Pflug from the Cretaceous of Lebanon. Paleontological Journal 44, 1353-1367. 
687 Zavialova, N., Buratti, N., Roghi G., 2010b. The ultrastructure of some Rhaetian Circumpolles

688 from southern England. Grana 49, 281-299.

689 Zhou, Z., 1983. A heterophyllous cheirolepidiaceous conifer from the Cretaceous of East China.

$690 \quad$ Palaeontology 26, 789-811.

691

692 Figure Captions

693 Figure 1: Maps and stratigraphy of the study area.

694 A. General map of Antarctica showing the study area in the Ross Sea region; red box 695 highlighting the study site at Carapace Nunatak.

696 B. Detailed map of red box area from A. Composite satellite image of the Ross Sea region, 697 included in the Taylor Glacier USGS topographic map, highlighting the study site at Carapace 698 Nunatak.

699 C. Geologic map of Carapace Nunatak, modified from Bradshaw (1987); samples were collected 700 from the ice-cored moraine on the E-NE side of Carapace Nunatak.

701 D. Generalized stratigraphic column of the Mawson Formation and Kirkpatrick Basalt at 702 Carapace Nunatak; fossiliferous chert and limestone occur as lenses within the basalt and 703 hyaloclastite that overlie the Carapace Sandstone Member of the Mawson Formation.

704 E. Rock sample of chert displaying soft sediment deformation and normal faults. Scale $=1 \mathrm{~cm}$. 
Figure 2: Suggested reconstruction of Classostrobus elliotii. The left side is an external view, and the right side displays internal details such as the position of the microsporangia. Illustration by Sara L. Taliaferro.

Plate I: Components of Classostrobus elliotii pollen cone from permineralizations, Early Jurassic of Antarctica.

Fig. 1. Apical portion of a longitudinal section of pollen cone. Note helical arrangement of microsporophylls $(\mathrm{S}=$ microsporophyll, $\mathrm{C}=$ cone axis). Scale $=1.0 \mathrm{~mm}$. Slide no. 29,833.

Fig. 2. Transverse section of pollen cone about halfway through specimen. Note masses of pollen grains (amber in color) within microsporangia, and annular arrangement of pollen sacs. Image taken of a peel still attached to the surface of the specimen $(\mathrm{S}=$ microsporophyll, $\mathrm{L}=$ associated leaf). Scale $=2.0 \mathrm{~mm} .17654 \mathrm{~F} 3$ bot peel no. 35. Slide no. 29,944.

Fig. 3. Annular cluster of 5 microsporangia with presumed microsporophyll stalk in the center (arrow), recognized by the presence of tracheids (see enlargement in Fig. 8). Scale $=0.3 \mathrm{~mm}$. $17613 \mathrm{~F}$ top alpha slide no. 22.

Fig. 4. Transverse section of a microsporophyll with rhomboidal head at the top left. Note epidermis (arrow) and opaque parenchymatous cells; cells below these are transfusion tissue (T). Scale $=0.5 \mathrm{~mm}$. Slide no. 29,912 .

Fig. 5. Dermal layers of microsporophyll $(\mathrm{E}=$ epidermis, $\mathrm{H}=$ hypodermis $)$. Scale $=25 \mu \mathrm{m}$. Slide no. 29,912 . 
726 Fig. 6. Single vascular trace from approximately the middle of microsporophyll stalk, showing

727 metaxylem tracheids with scalariform thickenings and possible protoxylem tracheids with

728 helical-annual thickeings (arrow). Scale $=50 \mu \mathrm{m}$. Slide no. 29,915.

729 Fig. 7. Transfusion tracheids of the microsporophyll. Note scalariform pitting (arrow). Scale $=50$

$730 \mu \mathrm{m}$. Slide no. 29,913.

731 Fig. 8. Higher magnification of central area indicated by arrow in Fig. 3, showing part of a

732 tracheid with scalariform thickenings (arrow). Scale $=30 \mu \mathrm{m}$. Slide no. 29,822.

733 Fig. 9. Uniseriate wall of pollen sac showing sporangial walls lacking opaque contents. Scale = $73450 \mu \mathrm{m}$. slide no. 29,813 .

735 Fig. 10. Detail of vascular bundle of one of the associated Brachyphyllum-type leaves.

736 Surrounding the vascular tissue are round cells (indicated by *) of unknown affinities that may

737 represent some type of secretory cell, form of transfusion tissue, or some type of thick-walled

738 fungal hyphae. Scale $=50 \mu \mathrm{m}$. Slide no. 29,812 .

740 Plate II: Pollen of Classostrobus elliotii. All SEM images from SEM stub no. J 2138.

741 Fig. 1. Light micrograph (LM) of numerous pollen grains within a microsporangium. Scale $=50$

$742 \mu \mathrm{m}$. Slide no. 29,940.

743 Fig. 2. LM of pollen grains still within a tetrad. Scale = 10 um. Slide no. 29,937.

744 Fig. 3. Scanning electron micrograph (SEM) of distal view of pollen grain. Note cryptopore (C)

745 and furrow (F). Scale $=5 \mathrm{um}$. 
746 Fig. 4. LM of side view displaying distal cryptopore (arrow). Scale = 10 um. Slide no. 29,937.

747 Fig. 5. SEM of distal view of pollen grain. Sexine $(\mathrm{S})$ is partially separated revealing preserved 748 nexine $(\mathrm{N})$ layer displaying the distal cryptopore $(\mathrm{C})$. Note perforations on nexine from contact 749 with columellae of the sexine. Scale $=10 \mathrm{um}$.

750 Fig. 6. LM of side view of pollen grain showing rimula (arrow) and striae in equatorial region.

751 Scale $=10 \mathrm{um}$. Slide no. 29,937.

752 Fig. 7. SEM of internal view of pollen grain showing rimula (arrow) and equatorial striae. Scale $753=10 \mathrm{um}$.

754 Fig. 8. LM of proximal view of trilete. Orbicules are indicated at arrow. Scale $=10$ um. Slide no. $755 \quad 29,939$.

756 Fig. 9. SEM of internal view of pollen grain showing trilete mark. Note linear striation patterns 757 (arrow) of sexine columellae. Scale $=10 \mathrm{um}$.

758 Fig. 10. Section of sexine layer displaying internal columellae on the left and external protruding 759 spinules on the right. Scale $=2 \mathrm{um}$.

760 Fig. 11. Internal view of smooth surface of nexine layer. Scale $=2 \mathrm{um}$.

761 Fig. 12. Orbicules with spinules. Scale $=2$ um. 


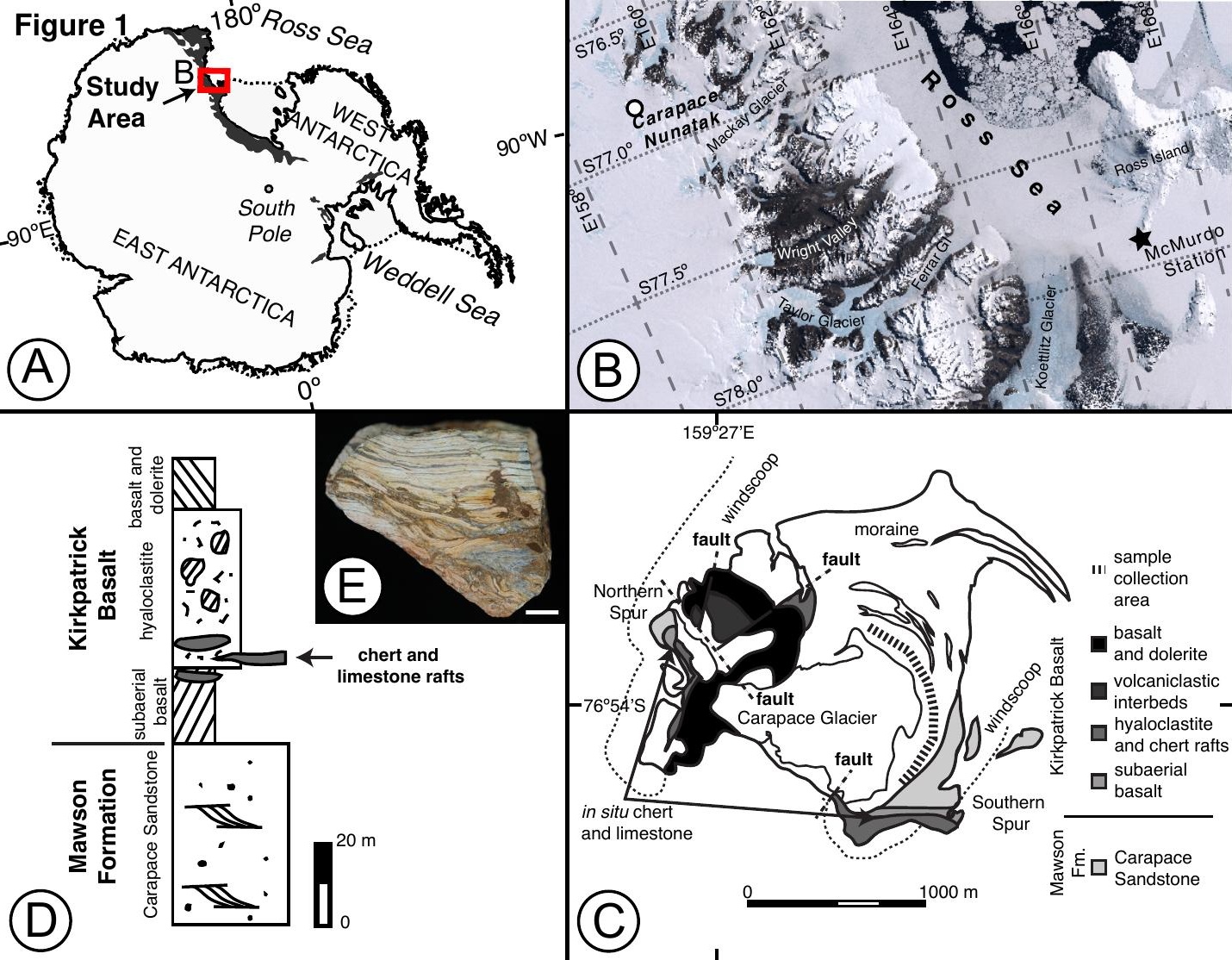


Figure 2

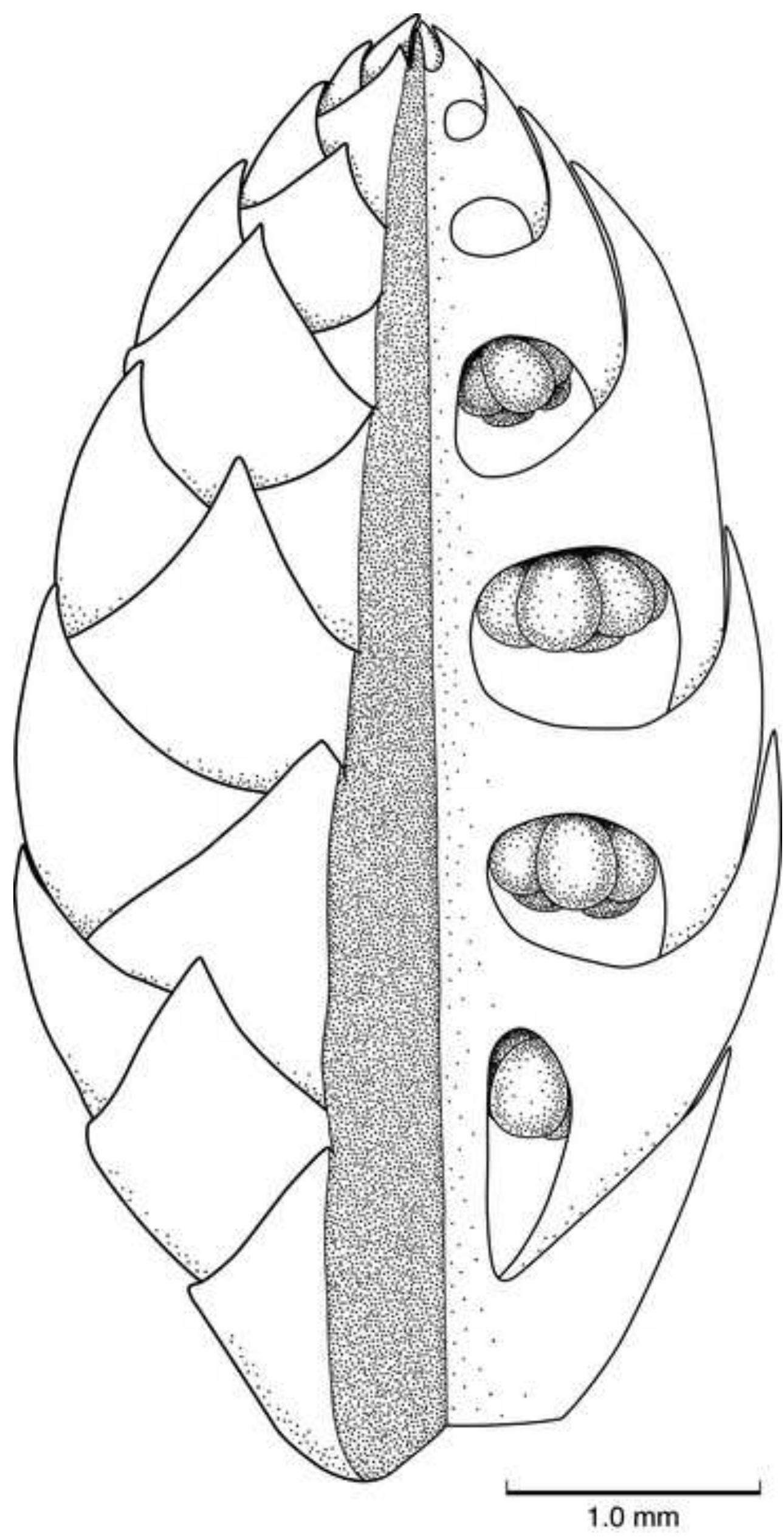




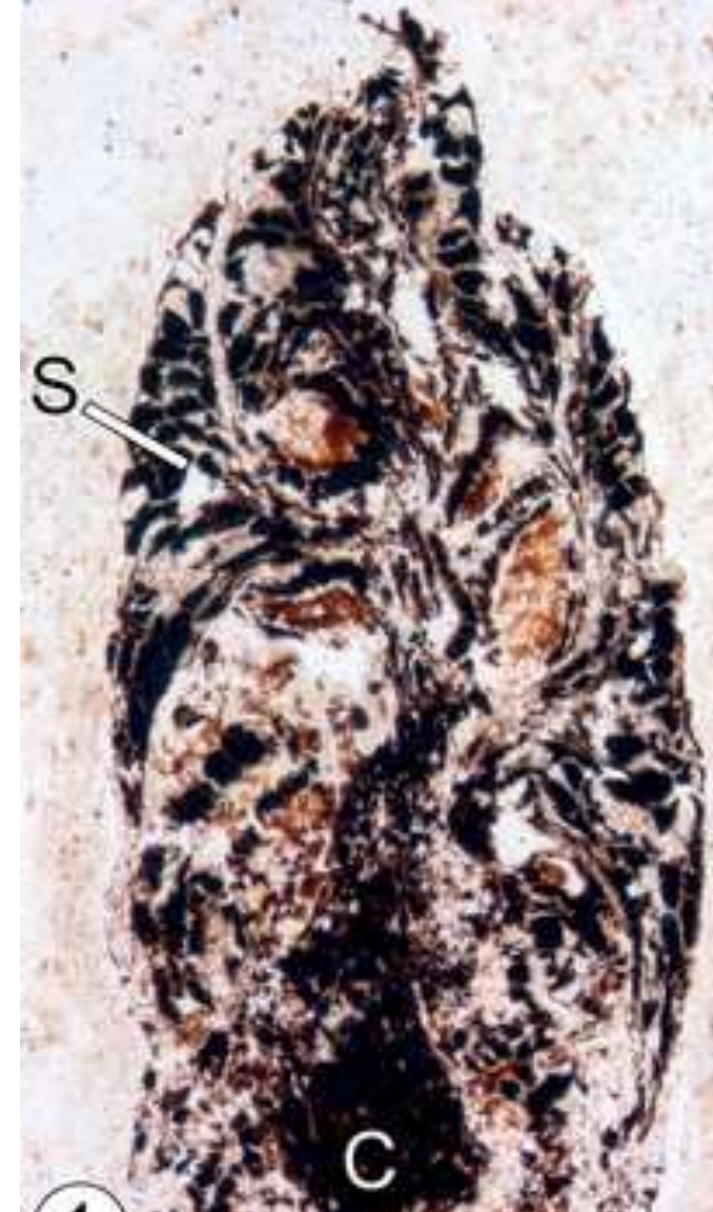

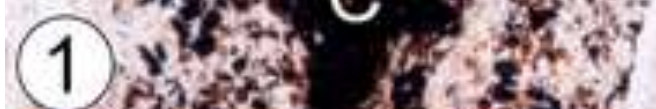
(1) Hox I I IS Wh of of 4.

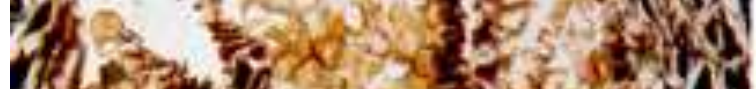
Moth s.t.

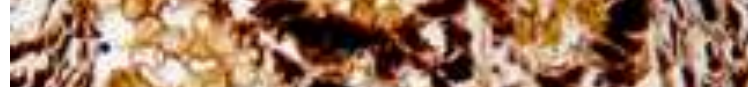

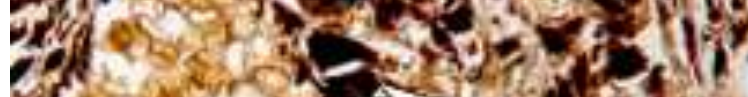

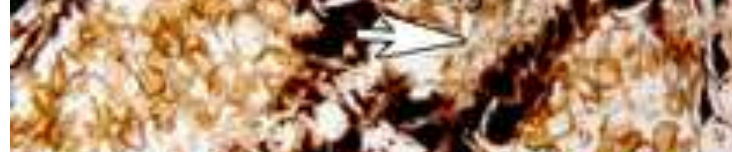

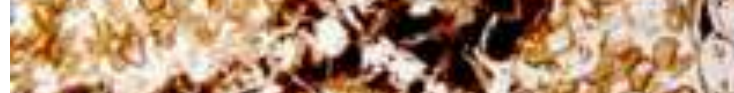
If $x$ in of on ow (3)
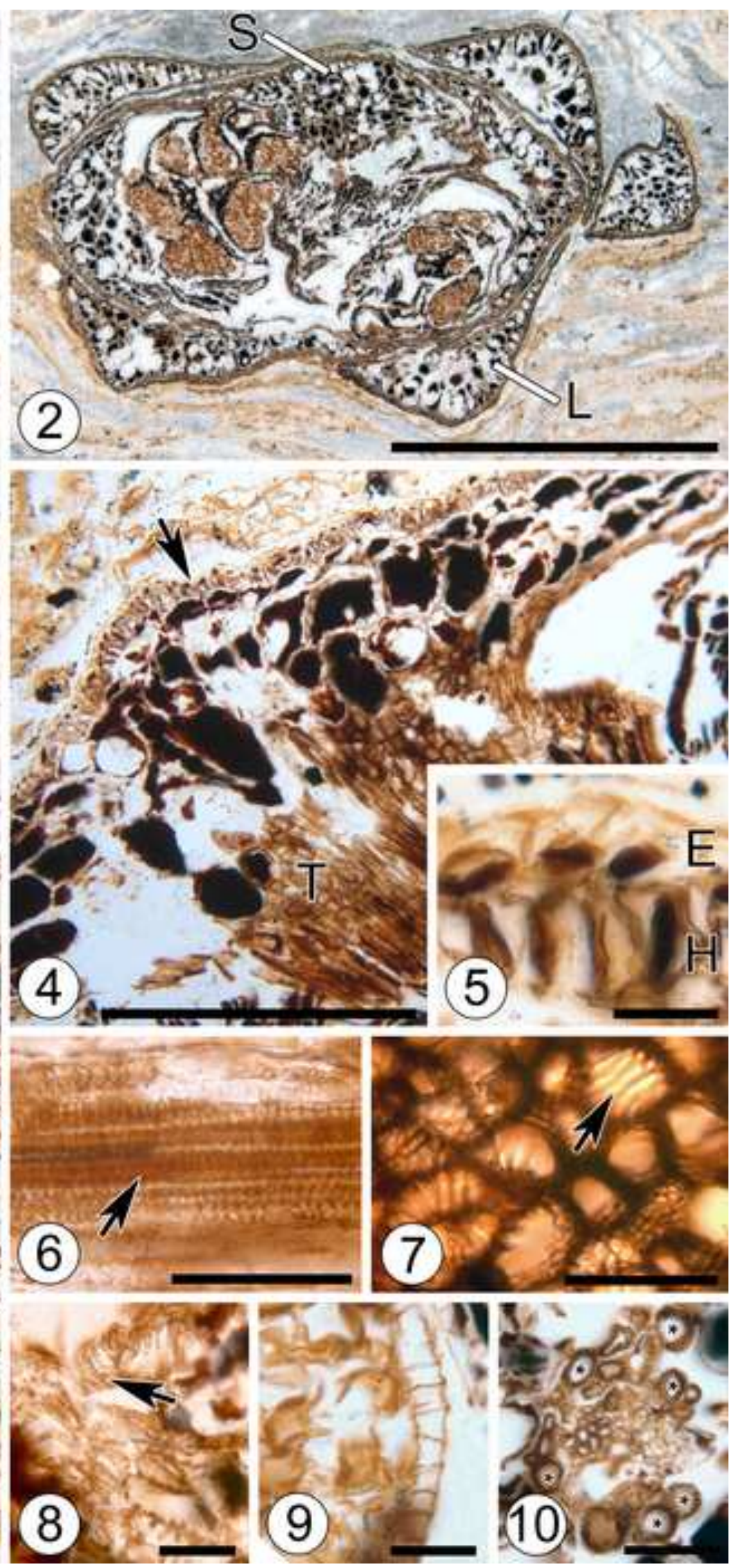

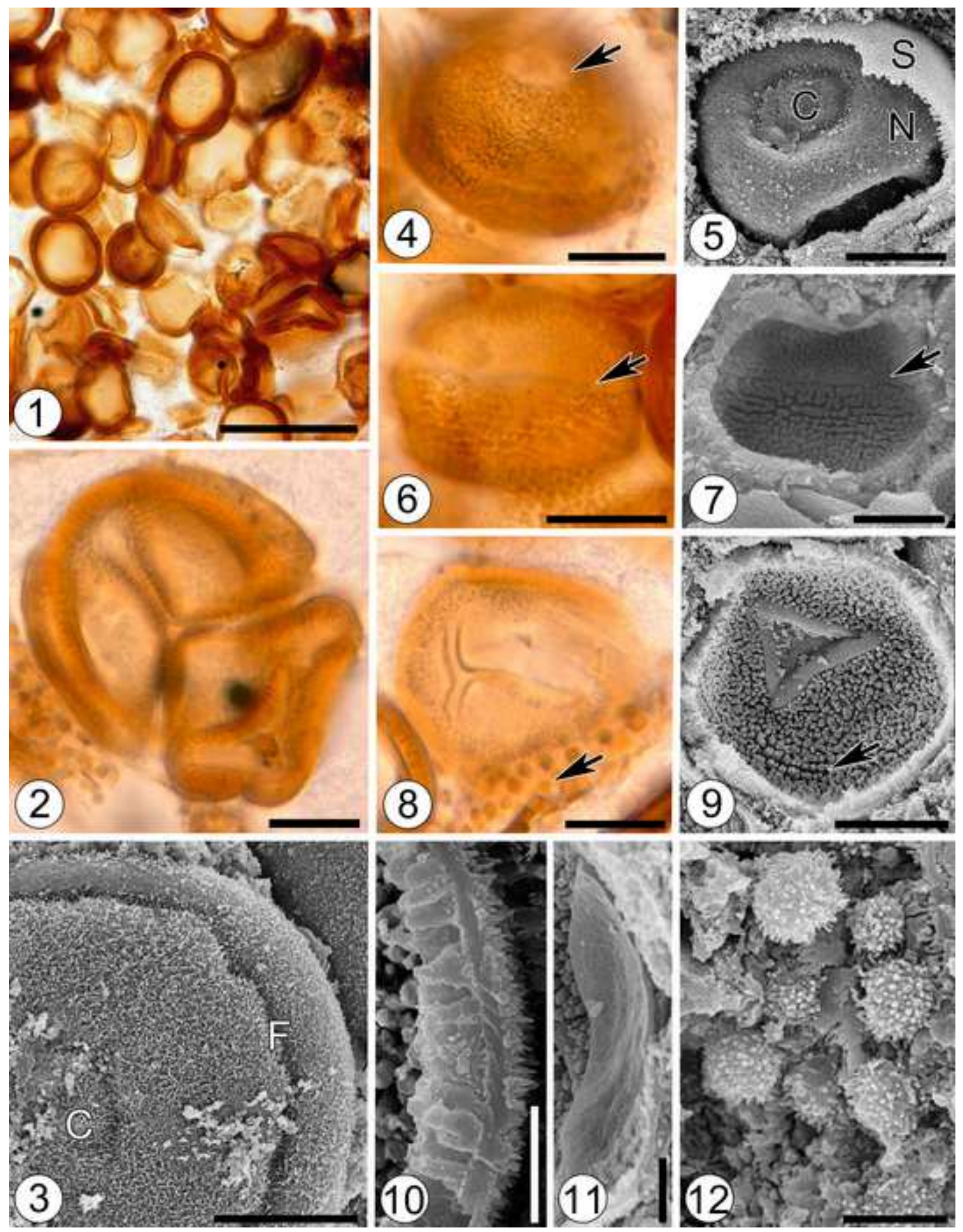